\title{
Determinants of Inflation in Sub-Saharan Africa: A Systematic Review
}

\author{
Mebtu Melaku \\ Lecturer, Department of Economics, Mekdela Amba University, Ethiopia
}

\begin{abstract}
Macroeconomic stability is the central aim of policymakers of most nations. Inflation is considered a crucial element of Macroeconomic stability. Empirical evidence confirmed the existence of a long-run relationship between inflation and other macroeconomic variables. The major objective of the study is to investigate the main determinants of inflation in sub-Saharan African countries. The study used a systematic review technique. Therefore in-depth literature review has been done on 11 studies undertaken in 9 sub-Saharan African countries. Accordingly, among the eight variables used for analysis, GDP, Broad money supply, Real exchange rate, and interest rate, is the main source of inflation. On the other hand import prices, Inflation expectations, public expenditure, and oil prices are found to determine inflation slightly.
\end{abstract}

Keywords: Determinant, Inflation, Sub-Saharan Africa

DOI: $10.7176 / \mathrm{DCS} / 11-3-02$

Publication date:March $31^{\text {st }} 2021$

\section{Introduction}

Macroeconomic stability is the central goal of policy makers of most nations. It promotes investment of all types, from conventional physical-capital investment to research and development (Romer, 2012). Inflation is one of the basic indicators macroeconomic stability. The term inflation has been defined in different ways. But as commonly used, it refers to a sustained increase in general price level of goods and services in an economy over a period of time. Moreover it is not a change in a specific price; rather it is an increase in the average level of prices (Barro, 1997).

When measured in terms of average price rise, all forms of inflation have no equal level of severity. They are commonly classified in to three. As: low inflation, galloping inflation and hyperinflation. Low inflation is a slow and predictable rise in inflation characterizes low inflation. It can be defined as a single digit annual inflation. Most countries have experienced low inflation since 2000. However; Galloping inflation is in double digit or triple digit range of 20,100, or 200 percent per years (Samualson and Nordhas, 2012). Lastly, hyperinflation is the most sever level of inflation. In 2008 the inflation rate in Zimbabwe was 24,000 percent (Mankiw, 2010). An extraordinary inflation such as this is called hyperinflation.

Theoretically the determinants of inflation can be categorized into two broad parts: demand-pull and cost push inflation. Or some time inflation may arise due to both demand-pull and cost-push factors. Demand pool inflation is when aggregate demand rises more than the economies productive potential and cost push inflation is when a rise in production costs of a given commodity leads to a rise in the price of that commodity.

Inflation redistributes income from wage earners and fixed income groups to profit recipients and from creditors to debtors. This in turn increases the number of poor hence resulting in more inequality (Jhingan, 1997). High inflation would also increase of uncertainty about future inflation. Increased uncertainty could be harmful to economy since it could discourage economic activities. Inflation also results in reduction of exports. This is because a rise in domestic input prices makes the price of domestically produced products expensive in the international market (Abeba, 2014). Most African countries are facing the problem of rise in inflation (AFDB, 2012). COVID- 19 has its own inflationary pressure on African economy. Ibrahim (2020) reported as Africa imports $90 \%$ of pharmaceuticals from outside the continent, the rise in the demand for pharmaceuticals in the world market causes supply side shortage on food and pharmaceuticals, in turn causing inflationary pressure on African economy.

Theory and Evidences suggest that managing inflation is a key factor to attain a healthy economy. Understanding the determinants of inflation is Essential for an effective control of inflation. So far, various studies were conducted to identify the determinants of Inflation. The objective of this systematic review is to investigate the major factors that determine inflation in Africa.

\section{Methodology}

The method of systematic review was used, to get full picture of the determinants of inflation in Africa. Random sampling was used to assure the representatives of sample. Relevance of the topic and geographical area of studies, are the criteria's for sample selection. Geographical area is the first criterion and after checking this, the studies were selected based on relevance of the topic. Studies conducted in eleven African countries have been used to collect the dependent and the majority of them are also the determinants of inflation in the short run. The study 
Vol.11, No.3, 2021

used descriptive statistical tool (percentage), to differentiate the most influential variables.

Table 1: Studies selected for review

\begin{tabular}{|c|c|c|c|}
\hline S.N & Author/s & country & Title \\
\hline 1 & Kibrom (2008) & Ethiopia & The Sources Of The Recent Inflationary Experience In Ethiopia \\
\hline 2 & Tsegay (2014) & Ethiopia & Determinants Of Recent Inflation (Case Study In Ethiopia) \\
\hline 3 & Sisay $(2008)$ & Ethiopia & Determinants of recent inflation in Ethiopia \\
\hline 4 & $\begin{array}{l}\text { Gyebi \& Boafo } \\
(2013)\end{array}$ & Ghana & $\begin{array}{l}\text { Macroeconomic Determinants Of Inflation In Ghana From } 1990 \text { - } \\
2009\end{array}$ \\
\hline 5 & Kirimi (2014) & Kenya & The Determinants Of Inflation In Kenya $(1970-2013)$ \\
\hline 6 & Ayinde et al (2010) & Nigeria & $\begin{array}{l}\text { Determinants Of Inflation In Nigeria: A Co Integration Approach } \\
\text { (Mansaray-Pearce Emmanuel Alpha, 2015) }\end{array}$ \\
\hline 7 & $\begin{array}{l}\text { Mansaray \& liu } \\
(2015)\end{array}$ & $\begin{array}{l}\text { Sierra } \\
\text { Leone }\end{array}$ & $\begin{array}{l}\text { The Determinants of Inflation in Sierra Leone: A Co-integration } \\
\text { Analysis }\end{array}$ \\
\hline 8 & $\begin{array}{ll}\text { Oatlhotse } & \& \\
\text { Nicholas (2018) } & \end{array}$ & $\begin{array}{l}\text { South } \\
\text { Africa }\end{array}$ & $\begin{array}{l}\text { The Main Determinants of Inflation in South Africa: an Empirical } \\
\text { Investigation }\end{array}$ \\
\hline 9 & $\begin{array}{l}\text { Almahdi \& Faroug } \\
(2020)\end{array}$ & Sudan & Modeling The Determinants Of Inflation In Sudan \\
\hline 10 & $\begin{array}{l}\text { Samuel A. \& Ussif } \\
\text { R. (2001) }\end{array}$ & Tanzania & Determinants of inflation in Tanzania \\
\hline 11 & Mally (2007) & Namibia & $\begin{array}{l}\text { An Econometrics Analysis Of The Determinants Of Inflation In } \\
\text { Namibia }\end{array}$ \\
\hline
\end{tabular}

Source: Reviewed literatures (2020)

\section{Results and Discussions}

\subsection{Description of Reviewed Literatures}

Under this topic some of the general characteristics of literatures in terms of country, nature of data, periods under study and models for analysis are presented.

Table 2: Characteristics of Reviewed Studies

\begin{tabular}{|l|l|l|l|l|l|}
\hline S.N & Author/s & country & $\begin{array}{l}\text { Nature of } \\
\text { Data }\end{array}$ & Time & Models \\
\hline 1 & Kibrom (2008) & Ethiopia & Time series & $1994-2008$ & VAR-ECM \\
\hline E & Tsegay (2014) & Ethiopia & Time series & $2001-2011$ & VAR \\
\hline 3 & Sisay (2008) & Ethiopia & Time series & $1997-2008$ & OLS-ECM \\
\hline 4 & Gyebi \& Boafo (2013) & Ghana & Time series & $1990-2009$ & OLS-ECM \\
\hline 5 & Kirimi (2014) & Kenya & Time series & $1970-2013$ & $\begin{array}{l}\text { OLS Co-integration- } \\
\text { ECM }\end{array}$ \\
\hline 6 & Ayinde et al (2010) & Nigeria & Time series & $1970-2006$ & Co-Integration-ECM \\
\hline 7 & Mansaray \& Liu (2015) & $\begin{array}{l}\text { Sierra } \\
\text { Leone }\end{array}$ & Time series & $1990-2013$ & Co-Integration-ECM \\
\hline 8 & $\begin{array}{l}\text { Oatlhotse \& Nicholas } \\
(2018)\end{array}$ & $\begin{array}{l}\text { South } \\
\text { Africa }\end{array}$ & Time series & $1970-2015$ & Co-Integration-ECM \\
\hline 9 & Almahdi \& Faroug (2020) & Sudan & Time series & $2000-2017$ & GMM \\
\hline 10 & $\begin{array}{l}\text { Samuel A. \& Ussif R. } \\
(2001)\end{array}$ & Tanzania & Time series & $1992-1998$ & OLS-ECM \\
\hline 11 & Mally (2007) & Namibia & Time series & $1993-2003$ & E.G-Co-integration \\
\hline
\end{tabular}

Source: Reviewed literatures (2020)

As it can be seen in the above table all the studies are conducted in Sub-Saharan Africa between the years 1970 to 2017 . Out of the total studies $8(66 \%)$ of them are conducted in the second decade of the $21^{\text {st }}$ century. Therefore, they provide us the recent phenomena of determinants of inflation in Sub-Saharan Africa. All of the studies used time series data for their analysis and applied appropriate econometric models.

\subsection{Determinants of Inflation}

Different factors are expected to affect the inflation, especially in the long run. In this study, however, eight influential variables are selected from literatures as of the following table. The sign $\sqrt{ }$ shows that the variables have been found significant in the long run from reviewed literatures. 
Table 3: Long run determinants of inflation

\begin{tabular}{|l|l|c|c|c|c|c|c|c|c|}
\hline \multirow{2}{*}{ S.N } & \multirow{2}{*}{ Author/s } & \multicolumn{7}{|l|}{ Independent variables (all are significant) } & \multicolumn{5}{l|}{} \\
\hline & & RGDP & G & M2 & OP & IMP & ERR & R & $P^{e}$ \\
\hline 1 & Kibrom (2008) & $\sqrt{ }$ & & $\sqrt{ }$ & & & & $\sqrt{ }$ & $\sqrt{ }$ \\
\hline 2 & Tsegay (2014) & $\sqrt{ }$ & & $\sqrt{ }$ & & & $\sqrt{ }$ & $\sqrt{ }$ & \\
\hline 3 & Sisay (2008) & $\sqrt{ }$ & & $\sqrt{ }$ & & & & $\sqrt{ }$ & $\sqrt{ }$ \\
\hline 4 & Gyebi \& Boafo (2013) & $\sqrt{ }$ & & $\sqrt{ }$ & & & $\sqrt{ }$ & $\sqrt{ }$ & \\
\hline 5 & Kirimi (2014) & $\sqrt{ }$ & & $\sqrt{ }$ & & & $\sqrt{ }$ & $\sqrt{ }$ & \\
\hline 6 & Ayinde et al (2010) & & & & $\sqrt{ }$ & $\sqrt{ }$ & $\sqrt{ }$ & $\sqrt{ }$ & \\
\hline 7 & Mansaray \& Liu (2015) & $\sqrt{ }$ & & $\sqrt{ }$ & & $\sqrt{ }$ & $\sqrt{ }$ & $\sqrt{ }$ & \\
\hline 8 & Oatlhotse \& Nicholas (2018) & $\sqrt{ }$ & $\sqrt{ }$ & & & $\sqrt{ }$ & $\sqrt{ }$ & & $\sqrt{ }$ \\
\hline 9 & Almahdi \& Faroug (2020) & $\sqrt{ }$ & $\sqrt{ }$ & $\sqrt{ }$ & & & $\sqrt{ }$ & & \\
\hline 10 & Samuel A. \& Ussif R. (2001) & $\sqrt{ }$ & & $\sqrt{ }$ & & $\sqrt{ }$ & $\sqrt{ }$ & & \\
\hline 11 & Mally (2007) & $\sqrt{ }$ & & $\sqrt{ }$ & & & & $\sqrt{ }$ & \\
\hline Summary & $10 / 11$ & $2 / 11$ & $9 / 11$ & $1 / 11$ & $5 / 11$ & $8 / 11$ & $8 / 11$ & $3 / 11$ \\
\hline
\end{tabular}

G-public Expenditure ; M2- Broad Money supply; OP-oil prices; IMP-price of Imports; ERR-Real Exchange rate; OD- overall budget Deficit; $\mathrm{R}$ - interest rate; $P^{e}=$ Price expectations

Source: Reviewed literatures (2020)

According to Table 3, the main factors affecting inflation are real GDP (90.9\%), Broad money supply (81.8\%), Real exchange rate $(72.7 \%)$ and interest rate $(72.7)$. They are found significant in the majority of the studies. The others variables: import price (45\%), Inflation expectations $(27.27 \%)$, public expenditure $(18.2 \%)$ and oil price $(9 \%)$ are also slightly important in explaining inflation.

GDP is one of the most important variables that determine inflation. As of Mally (2007), Samuel A. \& Ussif R. (2001), Sisay (2008), Oatlhotse \& Nicholas (2018), Almahdi \& Faroug (2020) and Kirimi (2014) an increase in real output contributes to reduce inflation. The implication is Governments can reduce inflation by increasing production. Contrary to this findings by Gyebi \& Boafo (2013), Kibrom (2008), Tsegay (2014) and Mansaray \& Liu confirmed that in increase in real output causes inflationary pressure. The justification is an increase in the expenditure pattern in general and of government in particular, on non-productive items will cause the general price level to move upwards. In the other way as income rises, demand for commodities rises, for a given supply of commodity, deriving food price up.

Quantity theorists say that inflation is always and everywhere a monetary phenomenon. Broad money supply, according to literatures influences inflation positively. Studies conducted by Samuel \& Ussif R. (2001), Gyebi \& Boafo (2013), Tsegay (2014), Kirimi (2014), Mansaray \& Liu, Kibrom (2008), Almahdi \& Faroug (2020) and Sisay (2008) confirmed increase in broad money supply aggravates inflation in the long run. Accordingly policy maker's interest in reducing inflation should pursue contractionary monetary policy.

Real exchange rate according to Samuel A. \& Ussif R. (2001), Tsegay (2014), Ayinde et al (2010) and Kirimi (2014) exchange rate has a positive effect on inflation. This is due to the fact that exchange rate increase is expected to make imported goods dearer and result in inflationary trend. Contrary to these findings, Gyebi \& Boafo (2013), Oatlhotse \& Nicholas (2018), Almahdi \& Faroug (2020) and Mansaray \& Liu confirmed that Real exchange rate variable $(\mathrm{E})$ is negatively related to inflation. That means exchange rate depreciation reduces the level of inflation.

Interest rate (lending interest rate) is found to have a positive impact on inflation Sisay (2008), Tsegay (2014), Kibrom (2008) and Kirimi (2014). That means an increase in interest rate causes inflation. Interest rates impact prices through two routes: demand for real money balances and cost of production, both of which inducing upward pressure on prices. Contrary to this evidences by Ayinde et al (2010) and Mansaray \& Liu shows that interest rate has negative effect on inflation.

\section{Conclusion}

The objective of the study was to identify the main determinants of in inflation in sub Saharan countries by a systematic review of original researches in the area. Although there is some difference in independent variable selection, depending on country context, there are variables that intersect most studies due to theoretical background. Accordingly eight theoretically justifiable variables had been selected.

The review confirmed that Gross domestic product, money supply, exchange rate and interest rate are found to have a contribution to determine inflation in the long run in most of the reviewed findings.

\section{Reference}

Abeba, T. (2014). Inflation and Growth relationships: A comparative study of Ethiopia and Uganda, Doctoral dissertation, Addis Ababa University Addis Ababa, Ethiopia.

AFDB (2012). The dynamics of inflation in Ethiopia and Kenya; a Working Paper (No. 151), http/www.afdb.org 
Almahdi, M., Faroug M. (2020). Modeling the Determinants of Inflation in Sudan Using Generalized Method of Moments for The Period 2000-2017. International Journal of Information Research and Review, 02(05).

Ayinde, Opeyemi, Akinsola, Grace, Omotesho, O. Ayinde, Kayode, (2010). Determinants Of Inflation In Nigeria: A Co Integration Approach.

Baro, R. J. (1997). Macroeconomics ( $5^{\text {th }}$ Ed). MIT Press, Masschusetts.

David, R. (2012). Advanced Macroeconomics ( ${ }^{\text {rd }}$ Ed). McGraw-Hill Companies, New York, America.

Ebrahim A. Z. (2020). Macroeconomic Impacts of COVID-19 in Sub-Saharan- Africa. Common Market for Eastern and South Africa. Retrieved from https://www.comesa.int/wpcontent/uploads/2020/06/Macroeconomic-Impacts-of-COVID-19-in-Sub-Saharan-Africa.-3.pdf

Fatukasi B. (2011). Determinants of Inflation in Nigeria: An Empirical Analysis.

Francis Gyebi \& Godfried K. Boafo, 2013. "Macroeconomic Determinants Of Inflation In Ghana From 1990 $\hat{A} \epsilon^{\prime \prime} 2009$," International Journal of Business and Social Research, MIR Center for Socio-Economic Research, vol. 3(6), pages 81-93, June.

Jhingan, M. L. (1997). Money, Banking and International Trade ( $5^{\text {th }}$ Ed): Vrinda Publications Ltd, Delhi, India.

Kibrom T. (2008). The Sources of the Recent Inflationary Experience In Ethiopia. A Thesis submitted to the School of Graduate Studies of Addis Ababa University in partial fulfillment of the requirements for the Degree of Master of Science in Economics (International Economics).

KIRIMI, W. N. (2014). The determinants of inflation in kenya(1970 2013). A research project presented to the School of Economics of the University of Nairobi in partial fulfilment of the requirement for the award of the degree of Master of Arts Economics.

Mally L. (2007). An Econometrics Analysis of the Determinants of Inflation in Namibia. A Thesis Submitted In Partial Fulfillment of the Requirements for the Degree of Master of Science of the University Of Namibia

Mansaray-Pearce E.A., Liu P. (2015). The Determinants of Inflation in Sierra Leone: A Cointegration Analysis. Journal of Economics and Sustainable Development, 6(6), 121-131.

N. Gregory Mankiw (2010). Macroeconomics ( $7^{\text {th }}$ Ed). Worth Publishers, 41 Madison Avenue New York, America.

Oatlhotse, M., Nicholas M. O. (2018). The Main Determinants of Inflation in South Africa: An Empirical Investigation. Journal of Organizations and Markets in Emerging Economies, 2(9), 212-229.

Paul, A. S. and William D. N. (2012). A book of Macro Economics ( $9^{\text {th }}$ Ed). Tata McGraw Hill Education Private Limited, New Delhi, India.

Samuel, A. Ussif R. (2020). Determinants of inflation in Tanzania, WP 2001: 12, Chr. Michelsen Institute Development Studies and Human Rights.

Sisay, M. (2008). Determinants of recent inflation in Ethiopia, MPRA Paper, University library of Munich, Germany. Retrieved from, https:/mpra.ub.uni-muenchen.de/29668/

Tsegay H. (2014). Determinants Of Recent Inflation (Case Study In Ethiopia). A Thesis submitted to the School of Graduate Studies of Mekelle University in partial fulfillment of the requirements for the Degree of Master of Science in Economics (Development Policy Analysis) 